\title{
Hemipogon trilobatus sp. nov. (Apocynaceae: Asclepiadoideae), a new microendemic from Chapada dos Veadeiros, Central Brazil
}

\author{
Cássia BITENCOURT ${ }^{1, *}$, Amanda P.B. SANTOS ${ }^{2}$, Cristiane SNAK $^{3}$ \& Alessandro RAPINI ${ }^{4}$ \\ 1,2,3,4 Universidade Estadual de Feira de Santana, Programa de Pós-Graduação em Botânica, \\ Av. Transnordestina, s/n, Novo Horizonte, 44036-900, Feira de Santana, Bahia, Brazil. \\ ${ }^{3}$ Universidade do Estado de Santa Catarina, Departamento de Engenharia de Pesca e \\ Ciências Biológicas, Rua Cel. Fernandes Martins 270, Progresso, 88790-000, Laguna, \\ Santa Catarina, Brazil. \\ *Corresponding author: ca.biten@gmail.com \\ ${ }^{2}$ Email: amanda.pricilla@hotmail.com \\ ${ }^{3}$ Email: cristianesnak@gmail.com \\ ${ }^{4}$ Email: rapinibot@yahoo.com.br
}

\begin{abstract}
Hemipogon s. str. (Apocynaceae: Asclepiadoideae) currently consists of three species sharing an erect herbaceous habit, narrow leaves and corona-less flowers with urceolate, internally bearded corolla, that are mainly distributed in savannahs of the Cerrado biodiversity hotspot, South America. Here, we describe and illustrate a new species of Hemipogon, H. trilobatus Bitencourt \& Rapini sp. nov., from an open savannah in Chapada dos Veadeiros, Central Brazil. Hemipogon trilobatus sp. nov. differs from the other species of the genus mainly by the presence of a reduced staminal corona with 3-lobed lobes, but also by opposite leaves and triangular anthers. Distribution and habitat data, as well as a key and a comparative table to distinguish the four species currently accepted in Hemipogon s. str., are provided. Based on criteria B2ab(i,ii,iii,iv) of the International Union for Conservation of Nature (IUCN), the species is provisionally assessed as Critically Endangered.
\end{abstract}

Keywords. Cerrado, Metastelmatinae, Neotropics, savannah, taxonomy.

Bitencourt C., Santos A.P.B., Snak C. \& Rapini A. 2020. Hemipogon trilobatus sp. nov. (Apocynaceae: Asclepiadoideae), a new microendemic from Chapada dos Veadeiros, Central Brazil. European Journal of Taxonomy 729: 1-10. https://doi.org/10.5852/ejt.2020.729.1185

\section{Introduction}

Hemipogon Decne. (Apocynaceae Juss.: Asclepiadoideae Burnett) belongs to the neotropical subtribe Metastelmatinae Endl. ex Meisn. and originally comprised erect perennial herbs with narrow leaves and urceolate, internally bearded, corona-less flowers (Fournier 1885). The genus was enlarged with the inclusion of twining plants with corona-less flowers classified in the American Astephanus R.Br. and erect herbs with corona-bearing flowers segregated from Metastelma R.Br. (Rapini et al. 2001; Rapini 2002). Phylogenetic studies (Ribeiro et al. 2012, 2014; Silva et al. 2012), however, showed that these two groups form a lineage predominantly distributed through the campos rupestres (rocky 
grasslands on quartzite outcrops) of the Espinhaço Range and are not closely related to Hemipogon acerosus Decne., the type of the genus. The phylogenetic inference indicates that the corona was lost several times within Metastelmatinae and thus Hemipogon should be treated under its narrow concept, comprising only three species, $H$. acerosus, $H$. setaceus Decne. and $H$. irwinii Fontella \& Paixão, or four, if $H$. acerosus var. platyphyllus Hoehne would be recognised at the species level (Bitencourt 2019). Using this narrow circumscription, Hemipogon is predominantly distributed in savannahs, and less often in campos rupestres of the Cerrado domain, in Central Brazil, reaching Bolivia, Peru and Paraguay.

Cerrado is a biodiversity hotspot (Myers et al. 2000) and the world's most diverse savannah, with around 6910 species of flowering plants, approximately 3815 of which are endemic (Silva \& Bates 2002; Flora do Brasil 2020). Despite its great importance, about half of the area originally occupied by Cerrado has been lost due to the implantation of pasture and commercial crops, mainly soybean and corn, and only $10 \%$ of its original area is protected in conservation units (Beuchle et al. 2015). Chapada dos Veadeiros in the Brazilian Cerrado houses savannahs in lowlands and patches of campos rupestres over mountaintops up to $1683 \mathrm{~m}$ a.s.l. (topographic map, https://www.arcgis.com/), and is considered a conservation priority area due to the high level of unique evolutionary diversity (Carvalho et al. 2015; Fenker et al. 2020).

Describing the biodiversity is an essential step to understand evolutionary and biogeographic patterns, and establish conservation strategies (Brach \& Boufford 2011; Ulloa et al. 2017). This task is especially relevant in areas under high pressure, such as the Cerrado hotspot. Herbaria are important source of new species (Prance 2001; Joppa et al. 2010; Bebber et al. 2010) and most undescribed species are discovered a long time after a first specimen was collected (Bebber et al. 2010). Here, we describe a new species from Chapada dos Veadeiros first collected 28 years ago. It fits the narrow concept of Hemipogon and is here provisionally assessed as Critically Endangered.

\section{Material and methods}

As part of a large study which aims to propose a new circumscription for the genus Hemipogon, specimens from different species of South American savannahs were examined in herbaria and collected in situ. Morphological measurements for this study were taken from specimens in the herbaria BHCB, CEN, HBR, HRB, HUEFS, IBGE, LPB, MBM, MO, NY, R, RB, UB, UFG, UFMT and USZ (acronyms according to the Index Herbariorum, Thiers continuously updated: http://sweetgum.nybg.org/science/ih/). Morphological terms follow Beentje (2016) and Endress et al. (2018). A provisional species conservation status was inferred based on IUCN (2019), according to the categories, criteria and conditions outlined in the Red List Guidelines. We used the GeoCAT tool (Bachman et al. 2011) to calculate the area of occupancy (AOO) using a $2 \times 2 \mathrm{~km}^{2}$ cell resolution. 


\title{
Results
}

\author{
Class Magnoliopsida Brongn. \\ Order Gentianales Bercht. \& J.Pres1 \\ Family Apocynaceae Juss. \\ Subfamily Asclepiadoideae Burnett \\ Genus Hemipogon Decne.
}

Hemipogon trilobatus Bitencourt \& Rapini sp. nov.

urn:lsid:ipni.org:names:77213240-1

Figs 1-2

\section{Diagnosis}

Flowers with reduced, apically 3-lobed corona lobes. Similar to H. acerosus due to the acicular leaves, sessile cymes and urceolate corolla, internally bearded along the lobe basal half, but can be distinguished by the opposite leaves (vs verticillate in H. acerosus) and presence of a corona (vs absence in H. acerosus).

\section{Etymology}

The epithet 'trilobatus' refers to the apically 3-lobed corona lobes.

\section{Type material}

BRAZIL • Goiás, Alto Paraíso de Goiás, Chapada dos Veadeiros, $9 \mathrm{~km}$ de Alto Paraíso para Vila São Jorge, Cachoeira São Bento; 9 Sep. 1994; M. Aparecida da Silva, T.S. Filgueiras, R.C. Mendonça, M.L.F. Resende, F.C.A. Oliveira and E. Cardoso 2320; holotype: IBGE[33546]!; isotype: RB[496900]!.

\section{Paratype}

BRAZIL • Goiás, Alto Paraíso de Goiás, Chapada dos Veadeiros; 14 Aug. 1992; H.D. Ferreira 2579; UFG[14114]!.

\section{Description}

Herbs to subshrub erect, 20-30 cm tall; stems 2 or 3, diverging at base, cylindrical, glabrescent; latex white. Leaves opposite, obliquely erect, sessile, acicular to narrowly elliptic, $0.7-1 \times 0.1-0.13 \mathrm{~mm}$, apex acute, base cuneate, margins entire, coriaceous, glabrescent. Cymes alternate, 2- or 4-flowered, subaxillary; bracts lanceolate, ca $1.5 \times 0.6 \mathrm{~mm}$, glabrous, sessile. Flowers with pedicel $1-1.5 \mathrm{~mm}$ long; sepals ovate, $1.5-1.6 \times 0.5-0.7 \mathrm{~mm}$, apex acute, glabrescent, axillary colleters not seen; corolla urceolate, probably cream or white, abaxially glabrescent, adaxially bearded from base to centre of lobes, tube $0.5-$ $0.7 \times 0.8-1.1 \mathrm{~mm}$, lobes triangular, $1-1.2 \times 0.8-1 \mathrm{~mm}$, apex acute and recurved; corona staminal, lobes short, at base of anthers, oblate, $0.3-0.45 \times 0.7-0.76 \mathrm{~mm}$, apex 3-lobed; anthers $0.45-0.5 \times 0.6-0.7 \mathrm{~mm}$, triangular, wings triangular, $0.3-0.4 \times 0.15-0.2 \mathrm{~mm}$, connective appendage oblong, $0.3-0.4 \mathrm{~mm}$ long, over gynostegium; corpusculum ellipsoid, $0.17-0.25 \times 0.08-0.1 \mathrm{~mm}$; caudicles horizontal, ca $0.05 \mathrm{~mm}$ long, subapically attached to pollinia; pollinia ellipsoid, $0.16-0.2 \times 0.06-0.08 \mathrm{~mm}$; style-head apically mammillate, included within corolla tube. Follicles not seen.

\section{Distribution, habitat and phenology}

Hemipogon trilobatus sp. nov. is known from a small population nearby the São Bento waterfall, in Chapada dos Veadeiros, Goiás, Brazil (Fig. 2). It grows in open savannah and wet grasslands locally known as "várzea" and was collected with flowers in August and September. The species has not been found since a fire burned the type locality (M.A. da Silva, pers. com., 2015). 


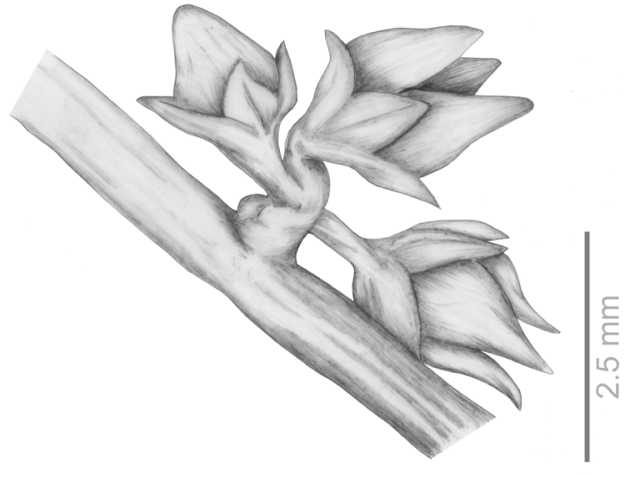

B

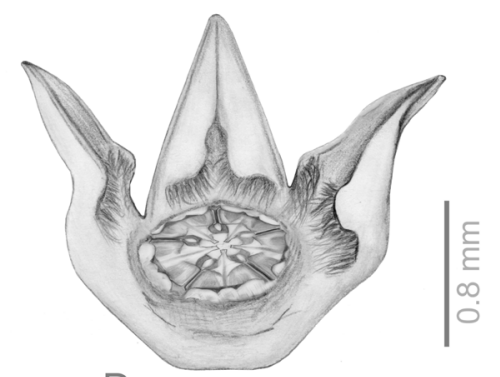

D
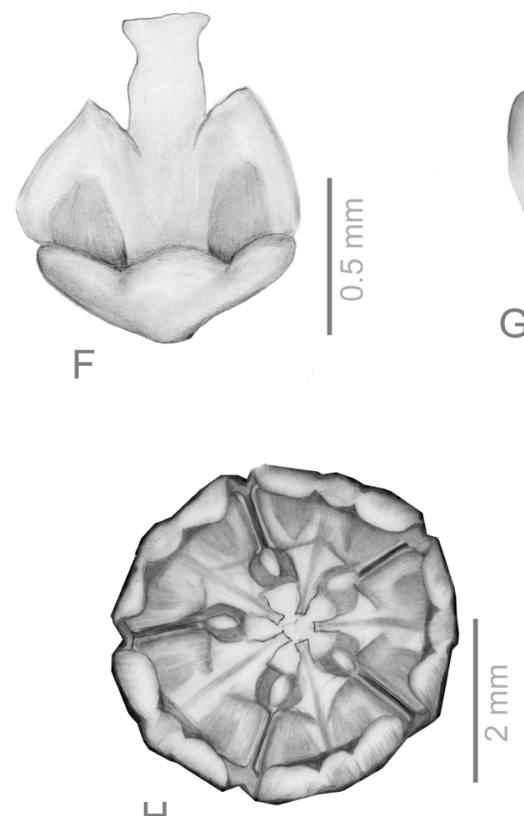

$\mathrm{H}$
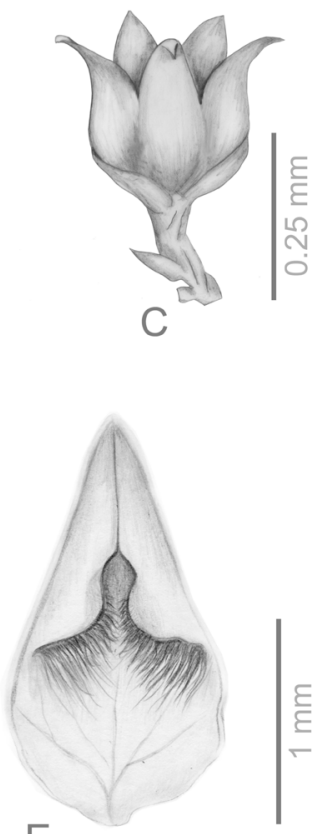

$\mathrm{E}$

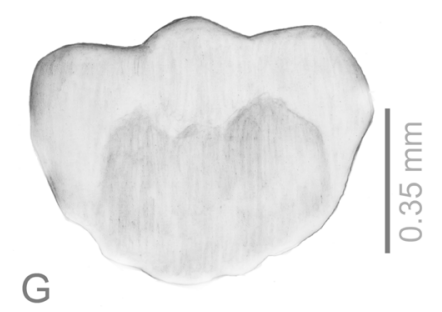

G

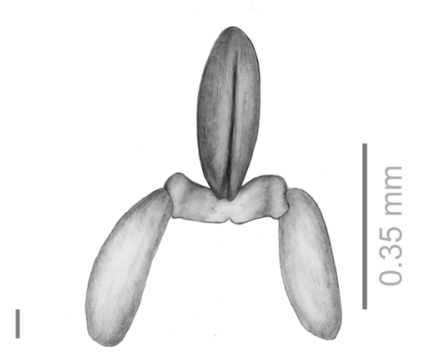

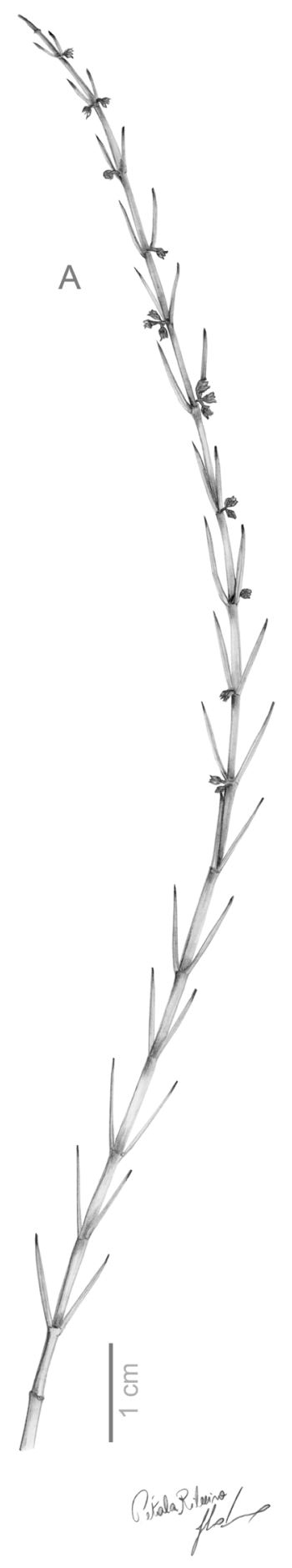

Fig. 1. Hemipogon trilobatus Bitencourt \& Rapini sp. nov. A. Habitus. B. Cyme with two flowers and a bud. C. Flower. D. Flower with calyx and two corolla lobes removed to show the gynostegium. E. Corolla lobe, adaxial view. F. Anther with a staminal corona lobe basally attached. G. Corona lobe showing the 3-lobed apex, adaxial view. H. Gynostegium, viewed from above. I. Pollinarium. Drawn by Pétala Gomes Ribeiro from the holotype (IBGE[33546]). 

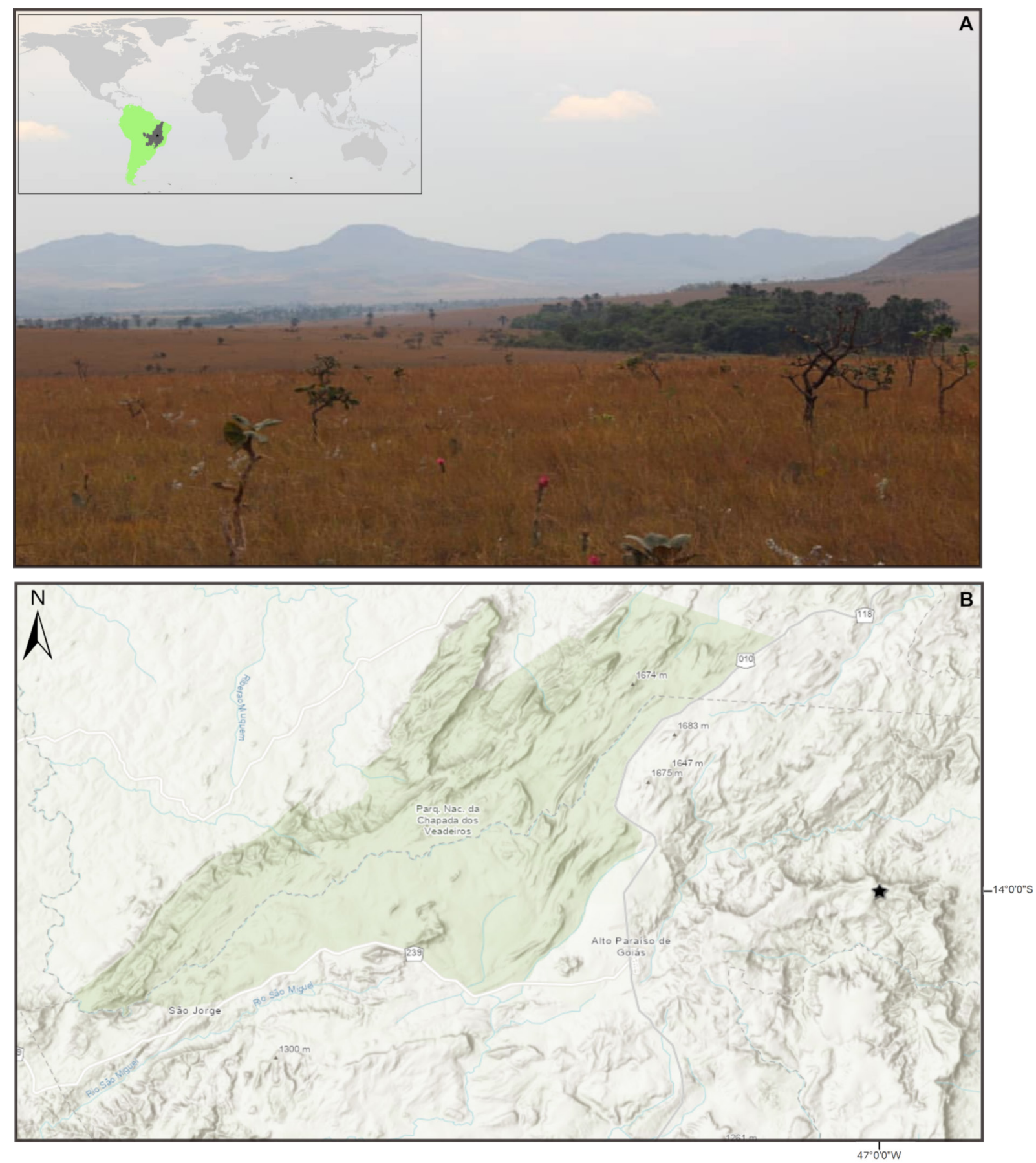

Fig. 2. Habitat and distribution of Hemipogon trilobatus Bitencourt \& Rapini sp. nov. A. Open savannah in Chapada dos Veadeiros, state of Goiás, Brazil. Photo by CB. B. Map showing the geographic distribution of $H$. trilobatus sp. nov. in the Cerrado domain (shaded area at reference map in A) and its occurrence (black star) nearby the Chapada dos Veadeiros National Park. Images and distribution maps were built and exported using ArcGIS online (https://www.arcgis.com). (C) Esri and its licensors, all rights reserved. 


\section{Provisional conservation status}

Hemipogon trilobatus sp. nov. is known from only two collections, both near the São Bento waterfall, in Chapada dos Veadeiros. Specimen labels provide no information about population density. However, the species is known to occur in a tourist location, surrounded by farms and cattle raising, has an area of occupancy (AOO) estimated at $8 \mathrm{~km}^{2}$, probably under continuing decline in geographic range and habitat quality. During fieldwork in the type locality, we did not find any specimen of $H$. trilobatus sp. nov. and the new species has not been recollected since 1994. Based on criteria B2ab(i,ii,iii,iv) of the International Union for Conservation of Nature (IUCN 2019) Red List assessment, we provisionally classify the species as Critically Endangered (CR).

\section{Taxonomic note}

Hemipogon trilobatus sp. nov. has narrow leaves, urceolate corolla with bearded lobes and was found in a savannah of Central Brazil. Together, these features support its classification in Hemipogon s. str. It most closely resembles $H$. acerosus based on the acicular leaves and sessile cymes, but differs from all other taxa in the genus by the opposite leaves and flowers with reduced corona lobes, as presented in the key below and Table 1 .

\section{Key to species of the genus Hemipogon s. str.}

1. Leaves opposite; flowers with short, 3-lobed staminal corona lobes

H. trilobatus Bitencourt \& Rapini sp. nov.

- Leaves verticillate or spirally arranged, flowers without corona .................................................... 2

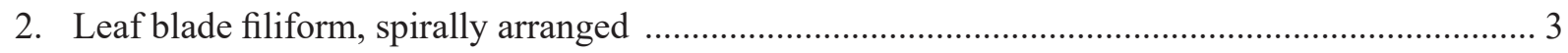

- Leaf blade acicular or ovate to lanceolate, verticillate .................................................................. 4

3. Corolla lobes $8.5-10 \mathrm{~mm}$ long, twisted in the bud, adaxially barbate on the basal half, sericeous on the apical half H. irwinii Fontella \& Paixão

- Corolla lobes 3.8-7 mm long, straight in the bud, adaxially barbate on the basal third, puberulous towards the apex

H. setaceus Decne.

4. Leaves sessile, the blade acicular, $\leq 1.5 \mathrm{~mm}$ wide

H. acerosus var. acerosus Decne.

- Leaves petiolate, the blade ovate to lanceolate, ca $3 \mathrm{~mm}$ wide

H. acerosus var. platyphyllus Hoehne

\section{Discussion}

Asclepiadoideae is a cosmopolitan subfamily with approximately 180 genera and 3200 species (Endress et al. 2018); around one third of this diversity is represented in the Americas (Good 1952; Rapini 2012). The proportion of narrowly distributed species and genera in the subfamily is high (Good 1952), and many species are known only from the type locality (Endress et al. 2018). Brazil harbours 35 native genera of Asclepiadoideae, only five of them including more than 15 species. Narrowly distributed species of Asclepiadoideae are common in the country (Rapini et al. 2001, 2002, 2009; Rapini 2010) and several Brazilian microendemics have been described in the last years (e.g., Bitencourt et al. 2020). This contributed to the increase of the number of Asclepiadoideae species in Brazil from 376 (Rapini et al. 2005) to 400 (Flora do Brazil 2020) in the last 15 years.

Some of the Asclepiadoideae microendemics are poorly known due to the limited number of collections. Hemipogon abietoides E.Fourn., described in Flora Brasiliensis (Fournier 1885) from a specimen collected by Riedel during the legendary expedition headed by Langsdorff through the Espinhaço Range of Minas Gerais, for instance, was recollected only 175 years after its original collection (Rapini 
Table 1. Diagnostic characters to distinguish the species of Hemipogon s. str.

\begin{tabular}{lcccc}
\hline Characters & $\begin{array}{c}\text { H. trilobatus } \\
\text { sp. nov. }\end{array}$ & H. acerosus & H. irwinii & H. setaceus \\
\hline Leaves & $\begin{array}{c}\text { opposite and } \\
\text { acicular } \\
\text { probably }\end{array}$ & $\begin{array}{c}\text { verticillate and } \\
\text { acicular }\end{array}$ & $\begin{array}{c}\text { spirally arranged } \\
\text { and filiform }\end{array}$ & $\begin{array}{c}\text { spirally arranged } \\
\text { and filiform }\end{array}$ \\
Corolla & cream & white & cream \\
Corona & present & absent & absent & absent \\
Anther & triangular & subtriangular & subsagittate & subtringular \\
Corpusculum & ellipsoid & ellipsoid & oblong & ellipsoid \\
\hline
\end{tabular}

et al. 2010). Molecular phylogenetic analyses (Ribeiro et al. 2012, 2014; Silva et al. 2012), however, showed that this species together with H. hemipogonoides (Malme) Rapini and H. hatschbachii (Fontella \& Marquete) Rapini, both erect herbs with narrow leaves and endemic to the campos rupestres (rocky grasslands on quartzite outcrops) of Serra do Cipó in the Espinhaço Range, belong to a lineage distant to Hemipogon s. str. and sister to the clade of twining plants predominantly distributed in the Espinhaço Range and assigned to the recently described Morilloa Fontella, Goes \& S.Cáceres (= the former American Astephanus; Fontella-Pereira et al. 2014).

Unpublished plastome phylogenetic analyses confirmed that convergences in Metastelmatinae are more common than previously supposed. They showed that two other species from the Espinhaço Range, also morphologically similar to Hemipogon s. lat. but endemic to cangas (rocky grasslands on iron outcrops) of the Iron Quadrangle form a clade separate from both Hemipogon s. str. and Morilloa (Bitencourt 2019). The two species were recently described in the non-monophyletic Ditassa R.Br., as D. cangae Bitencourt \& Rapini and D. ferricola Bitencourt \& Rapini (Bitencourt et al. 2020). The erect habit, narrow leaves and urceolate corolla of Hemipogon trilobatus sp. nov. may also represent another example of morphological convergence. In preliminary phylogenetic analyses of ITS rDNA sequence data, $H$. acerosus and $H$. trilobatus sp. nov. appeared in a polytomy, but not closely related to Morilloa (unpublished results). The geographical distribution of H. trilobatus sp. nov., restricted to an open savannah in Central Brazil rather than cangas or campos rupestres of Espinhaço Range, can be regarded as additional evidence for its placement in Hemipogon until further phylogenetic studies may provide new insights towards a new generic circumscription in Metastelmatinae and a more confident placement for H. trilobatus sp. nov.

\section{Acknowledgements}

We thank Betânia Goes and Maria Aparecida Silva for supporting CB's visit to IBGE Reserve, Marina Resende (IBGE) and Rafaela Campostrini Forzza (RB) for specimen loans, Moabe F. Fernandes for help with fieldwork and suggestions on a first draft of the manuscript, three anonymous reviewers and the topical editor Frederik Leliaert for corrections and suggestions and Pétala Gomes Ribeiro for the illustration. This work is part of the PhD thesis of $\mathrm{CB}$, developed at PPGBot-UEFS with a fellowship from the Coordenação de Aperfeiçoamento de Pessoal de Nível Superior - Brasil (CAPES) - Finance Codes \#1514632 (DS) and \#88881.135731/2016-01 (PDSE), and supported by the project Universal (CNPq \#485468/2013-1). CB acknowledges the International Association of Plant Taxonomy (IAPT, 2016) grant, Neotropical Grasslands Conservancy memorial (NGC, 2016) and Shirley A. Graham (Missouri Botanical Garden, 2018) Fellowships. AR is supported by CNPq (Productivity Fellowship no. 307396/2019-3). 


\section{Authors' contributions}

AR recognised the new species. $\mathrm{CB}$ examined the types and paratypes, described the new species and wrote a first draft of the manuscript. $\mathrm{CB}$ and $\mathrm{AR}$ revised the manuscript with additional contributions from APBS and CS. All authors revised the final version of the manuscript.

\section{References}

Bachman S., Moat J., Hill A.W., Torre J. \& Scott B. 2011. Supporting Red List threat assessments with GeoCAT: geospatial conservation assessment tool. ZooKeys 150: 117-126.

https://doi.org/10.3897/zookeys.150.2109

Bebber D.P., Carine M.A., Wood J.R.I., Wortley A.H., Harris D.J., Prance G.T., Davidse G., Paige J., Pennington T.D., Robson N.K.B. \& Scotland R.W. 2010. Herbaria are a major frontier for species discovery. Proceedings of the National Academy of Sciences of the United States of America 107: 22169-22171. https://doi.org/10.1073/pnas.1011841108

Beentje H. 2016. The Kew Plant Glossary - An Illustrated Dictionary of Plant Terms. Royal Botanic Gardens, Kew.

Beuchle R., Grecchi R.C., Shimabukuro Y.E., Seliger R., Eva H.D., Sano E. \& Achard F. 2015. Land cover changes in the Brazilian Cerrado and Caatinga biomes from 1990 to 2010 based on a systematic remote sensing sampling approach. Applied Geography 58: 116-127.

https://doi.org/10.1016/j.apgeog.2015.01.017

Bitencourt C. 2019. Explorando a diversificação das Apocynaceae na era da filogenômica, com ênfase nas espécies de Hemipogon. $\mathrm{PhD}$ thesis, Universidade Estadual de Feira de Santana, Brazil.

Bitencourt C., Fernandes M.F., Espírito Santo F.S. \& Rapini A. 2020. Two new Critically Endangered species of Ditassa (Apocynaceae) from the threatened cangas of the Iron Quadrangle, Minas Gerais, Brazil. Plant Ecology and Evolution 153: 246-256. https://doi.org/10.5091/plecevo.2020.1669

Brach A.R. \& Boufford D.E. 2011. Why are we still producing paper floras? Annals of the Missouri Botanical Garden 98: 297-300. https://doi.org/10.3417/2010035

Carvalho Jr O.A., Guimarães R.F., Souza Martins É. \& Gomes R.A.T. 2015. Chapada dos Veadeiros: the highest landscapes in the Brazilian Central Plateau. In: Vieira B.C., Salgado A.A.R. \& Santos L.J.C. (eds) Landscapes and Landforms of Brazil. Vol. 1: 221-230. Springer, Dordrecht. https://doi.org/10.1007/978-94-017-8023-0_20

Endress M.E., Meve U., Middleton D.J. \& Liede-Schumann S. 2018. Apocynaceae. In: Kadereit J.W. \& Bittrich V. (eds) Flowering plants. Eudicots. Apiales and Gentianales (except Rubiaceae), in Kubitzki K. (ed.) The Families and Genera of Vascular Plants. Vol. 15: 207-411. Springer, Cham. https://doi.org/10.1007/978-3-319-93605-5_3

Flora do Brasil. 2020. Jardim Botânico do Rio de Janeiro. Available from http://floradobrasil.jbrj.gov.br [accessed 10 Mar. 2018].

Fenker J., Domingos F.M.C.B., Tedeschi L.G., Rosauer D.F., Werneck F.P., Colli G.R., Ledo R.M.D., Fonseca E.M., Garda A.A., Tucker D., Sites Jr J.W., Breitman M.F., Soares F., Giugliano L.G. \& Moritz C. 2020. Evolutionary history of Neotropical savannas geographically concentrates species, phylogenetic and functional diversity of lizards. Journal of Biogeography 46: 1130-1142.

https://doi.org/10.1111/jbi.13800

Fontella-Pereira J., Santos R.G.P., Goes M.B. \& Moral S.A.C. 2014. Notas taxonómicas sobre Hemipigon subgen. Astephanopsis y descripción de un nuevo género (Apocynaceae, Asclepiadoideae, Asclepiadeae, Metastelmatinae). Bonplandia 23: 25-31. https://doi.org/10.30972/bon.2311239 
Fournier E.P.N. 1885. Asclepiadaceae. In: Martius C.F.P. \& Eichler A.W. (eds) Flora Brasiliensis. Vol. 6, pt. 4: 189-332. Typographia Regia, Monachii.

Good R. 1952. An atlas of the Asclepiadaceae. New Phytologist 51: 198-209.

https://doi.org/10.1111/j.1469-8137.1952.tb06126.x

IUCN. 2019. Guidelines for Using the IUCN Red List Categories and Criteria, Version 14. IUCN, Gland/Cambridge.

Joppa L.N., Roberts D.L. \& Pimm S.L. 2010. How many species of flowering plants are there? Proceedings of the Royal Society Biological Sciences 278: 554-559. https://doi.org/10.1098/rspb.2010.1004

Myers N., Mittermeier R.A., Mittermeier C.G., Fonseca G.A.B. \& Kent J. 2000. Biodiversity hotspots for conservation priorities. Nature 403: 853-858. https://doi.org/10.1038/35002501

Prance G.T. 2001. Discovering the plant world. Taxon 50: 345-359. https://doi.org/10.2307/1223885

Rapini A. 2002. Six new species of Ditassa R. Br. from the Espinhaço Range, Brazil, with notes on generic delimitation in Metastelmatinae (Apocynaceae-Asclepiadoideae). Kew Bulletin 57: 565-583. https://doi.org/10.2307/4110986

Rapini A. 2010. Revisitando as Asclepiadoideae (Apocynaceae) da Cadeia do Espinhaço. Boletim de Botânica da Universidade de São Paulo 28: 97-123.

https://doi.org/10.11606/issn.2316-9052.v28i2p97-123

Rapini A. 2012. Taxonomy "under construction": advances in the systematics of Apocynaceae, with emphasis on the Brazilian Asclepiadoideae. Rodriguésia 63: 75-88.

https://doi.org/10.1590/S2175-78602012000100007

Rapini A., Mello-Silva R. \& Kawasaki M.L. 2001. Asclepiadoideae (Apocynaceae) da Cadeia do Espinhaço de Minas Gerais, Brasil. Boletim de Botânica da Universidade de São Paulo 19: 55-169. https://doi.org/10.11606/issn.2316-9052.v19i0p55-169

Rapini A., Mello-Silva R. \& Kawasaki M.L. 2002. Richness and endemism in Asclepiadoideae (Apocynaceae) from the Espinhaço Range of Minas Gerais, Brazil - a conservationist view. Biodiversity and Conservation 11: 1733-1746. https://doi.org/10.1023/A:1020346616185

Rapini A., Goyder D.J., Konno T.U.P. \& Farinaccio M.A. 2005. Progress in asclepiad taxonomy: species numbers in Brazilian Asclepiadoideae (Apocynaceae) through time. Kew Bulletin 60: 111-115. Available from http://www.jstor.org/stable/4110890 [accessed 26 Nov. 2020].

Rapini A., Silva R.F.S. \& Sampaio L.N.P. 2009. Apocynaceae. In: Giulietti A.M., Rapini A., Andrade M.J.G., Queiroz L.P. \& Silva J.M.C. (eds) Plantas Raras do Brasil: 54-64. Conservation International, Belo Horizonte.

Rapini A., Ribeiro P.L. \& Silva U.C.S. 2010. 667. Hemipogon abietoides. Curtis's Botanical Magazine 27: 23-35. https://doi.org/10.1111/j.1467-8748.2010.01681.x

Ribeiro P.L., Rapini A., Silva U.C.S., Konno T.U.P., Damascena L.S. \& van den Berg C. 2012. Spatial analyses of the phylogenetic diversity of Minaria (Apocynaceae): assessing priority areas for conservation in the Espinhaço Range, Brazil. Systematics and Biodiversity 10: 317-331.

https://doi.org/10.1080/14772000.2012.705356

Ribeiro P.L., Rapini A., Damascena L.S. \& van den Berg C. 2014. Plant diversification in the Espinhaço Range: Insights from the biogeography of Minaria (Apocynaceae). Taxon 63: 1253-1264.

https://doi.org/10.12705/636.16

Silva J.M.C. \& Bates J.M. 2002. Biogeographic patterns and conservation in the South American Cerrado: a Tropical savanna hotspot. Bioscience 52: 225-233.

https://doi.org/10.1641/0006-3568(2002)052[0225:BPACIT]2.0.CO;2 
Silva U.C.S., Rapini A., Liede-Schumann S., Ribeiro P.L. \& van den Berg C. 2012. Taxonomic considerations on Metastelmatinae (Apocynaceae) based on plastid and nuclear DNA. Systematic Botany 37: 795-806. https://doi.org/10.1600/036364412X648733

Thiers B. continuously updated. Index Herbariorum: a global directory of public herbaria and associated staff. New York Botanical Garden's Virtual Herbarium.

Available from http://sweetgum.nybg.org/science/ih/ [assessed 26 Jul. 2020].

Ulloa C., Acevedo-Rodríguez P., Beck S., Belgrano M.J., Bernal R., Berry P.E., Brako L., Celis M., Davidse G., Forzza R.C., Gradstein S.R., Hokche O., León B., León-Yánez S., Magill R.E., Neill D.A., Nee M., Raven P.H., Stimmel H., Strong M.T., Villaseñor J.L., Zarucchi J.L., Zuloaga F.O. \& Jørgensen P.M. 2017. An integrated assessment of the vascular plant species of the Americas. Science 358: 1614-1617. https://doi.org/10.1126/science.aao0398

Manuscript received: 6 August 2020

Manuscript accepted: 5 October 2020

Published on: 11 December 2020

Topic editor: Frederik Leliaert

Desk editor: Radka Rosenbaumová

Printed versions of all papers are also deposited in the libraries of the institutes that are members of the EJT consortium: Muséum national d'histoire naturelle, Paris, France; Meise Botanic Garden, Belgium; Royal Museum for Central Africa, Tervuren, Belgium; Royal Belgian Institute of Natural Sciences, Brussels, Belgium; Natural History Museum of Denmark, Copenhagen, Denmark; Naturalis Biodiversity Center, Leiden, the Netherlands; Museo Nacional de Ciencias Naturales-CSIC, Madrid, Spain; Real Jardín Botánico de Madrid CSIC, Spain; Zoological Research Museum Alexander Koenig, Bonn, Germany; National Museum, Prague, Czech Republic. 